\title{
Taxonomic studies in the Aizoaceae from South Africa: three new species and some new combinations
}

\author{
C. KLAK*
}

Keywords: Aizoaceae, new species, new combinations, South Africa, taxonomy

\section{ABSTRACT}

\begin{abstract}
Two new species of Brownanthus, B. glareicola Klak and B. fraternus Klak and one new species of Scopelogena. $S$. bruynsii Klak are described. S. gracilis L.Bolus is reduced to synonymy under $S$. verruculata (L.) L. Bolus. Three new combinations are made: Antimima excedens (L.Bolus) Klak. Erepsia dunensis (Sond.) Klak and Hammeria meleagris (L.Bolus) Klak and full synonomy is given. Lampranthus maximilianii (Schltr. \& A.Berger) L.Bolus is transferred back to Braunsia maximilianii (Schltr. \& A Berger) Schwantes and the identity of Ruschia polita L.Bolus is discussed. The taxonomic position of Mesembryanthemum purpureostylum L.Bolus is clarified.
\end{abstract}

\section{Antimima N.E.Br.}

This genus was described by N.E. Brown (1930) and later amended by Dehn (1989). Recently about 100 species were moved from Ruschia Schwantes to Antimima (Hartmann 1998a). However, no revision of the species is available. Although species of Ruschia and Antimima were for many years included in one genus, they are thought to be unrelated, due to differences in the morphology of their respective capsules. Antimima has capsules of the Leipoldtia type. These have relatively large, stalked closing bodies, which is considered to be an apomorphy for the Leipoldtia group (Hartmann 1991). Whereas all other genera with a Leipoldtia type of fruit are multilocular, capsules of Antimima are always 5-locular. As a consequence of this circumscription of Antimima, a further species is now moved from Ruschia to Antimima.

Antimima excedens (L.Bolus) Klak, comb. nov.

Ruschia excedens L.Bolus, Notes on Mesembryanthemum and allied genera part 3: 278 (1954). Type: South Africa, Vanrhynsdorp Div., Knersvlakte. Sept. 1950), Meyer SUGI2505, sheet 3 (BOL. lecto., here designated)

\section{Braunsia Schwantes}

Braunsia is a small genus of about four or five species which is thought to be related to the Lampranthus group (Hartmann 1991). The echinate seeds and leaves that are fused for a quarter to half of their length. with white, cartilagenous margins, were so far considered to be the main characteristics of the genus.

The lack of echinate seeds in one of the species, Braunsia maximilianii, prompted L. Bolus (1965) to place it rather in Lampranthus N.E.Br., which never has echinate seeds. This view stood in contrast to the earlier opinion of N.E. Brown (1929). He considered the pres-

\footnotetext{
* Bolus Hetharium, University of Cape Town, 7701 Rondebosch. Cape Town.e-mail: klak@botzoo uct.ac.za

MS received 1999-(04-08
}

ence or absence of echinate seeds to be unimportant in terms of the genus boundaries, since he had noticed that this character is found in completely unrelated taxa.

Recent investigations now confirm the views of Brown. Apart from the morphology of the flowers and leaves, which are typical for Braunsia, the morphology of the capsules excludes this species from Lampranthus. In contrast to Lampranthus, where the expanding keels always diverge from the base, those of Braunsia are parallel for most of their length and only diverge towards the tips. In addition, the covering membranes in Lampranthus are always complete and more or less firm. often with additional closing devices below the covering membranes. In Braunsia the covering membranes only cover the locules partly, are fairly flexible and do not have any additional closing devices. The capsules of Lampranthus maximilianii were found to be typical of species of Braunsia in all these details. Therefore the older name, Braunsia maximilianii is re-instated here.

Braunsia maximilianii (Schltr. \& A.Berger) Schwant. in Gartenwelt 32: 644 (1928a).

Mesembryanthemum maximiliani Schltr \& A.Berger: 633 (1922) Echinus maximilianii (Schltr \& A.Berger) N.E.Br.: 57 (1929). Lampranthus maximilianii (Schltr \& A.Berger) L. Bolus: 172 (1965). Type: Pakhuisberg. 12 Aug. 1897. Schlechter 10817 (B. holo.; BOL!, GRA !)

Mesembrvanthemum apiculatum var mutica L.Bolus: 149 (1913) Type: Gifberg. Sept. 1911. Phillips 7664 (BOL. holo.!).

M. phillipsii L.Bolus: 5 (1925). Type: Schlechter 10817 (B: BOL!, holo.; GRA!, iso.).

M. binum L.Bolus: t. 263 (1927), non N.E.Br. Type: Vanthynsdorp. Rood NBGI249/23 (BOL. holo.).

\section{Specimens examined}

WESTERN CAPE - 3118 (Vanrhynsdorp): Gifherg Plateau. (-DC). Acrkks 14897 (BOL); plateau hetween Matsikamma and Gifberg. (-DC). Esierhuysen 30750 (BOL); Nardouw; (-DD), L. Bolus s.n. (BOL); Cederberg. Krasibosberg. (-DD). Klak 437 (BOL). 3119 (Calvinia): top of Vanihyn's Pass, (-AC). Esterhuysen 7773 (BOL): entrance to Oorlog's Kloof, ( $-\mathrm{AC})$, L. Bolus BH19232 (BOL); 


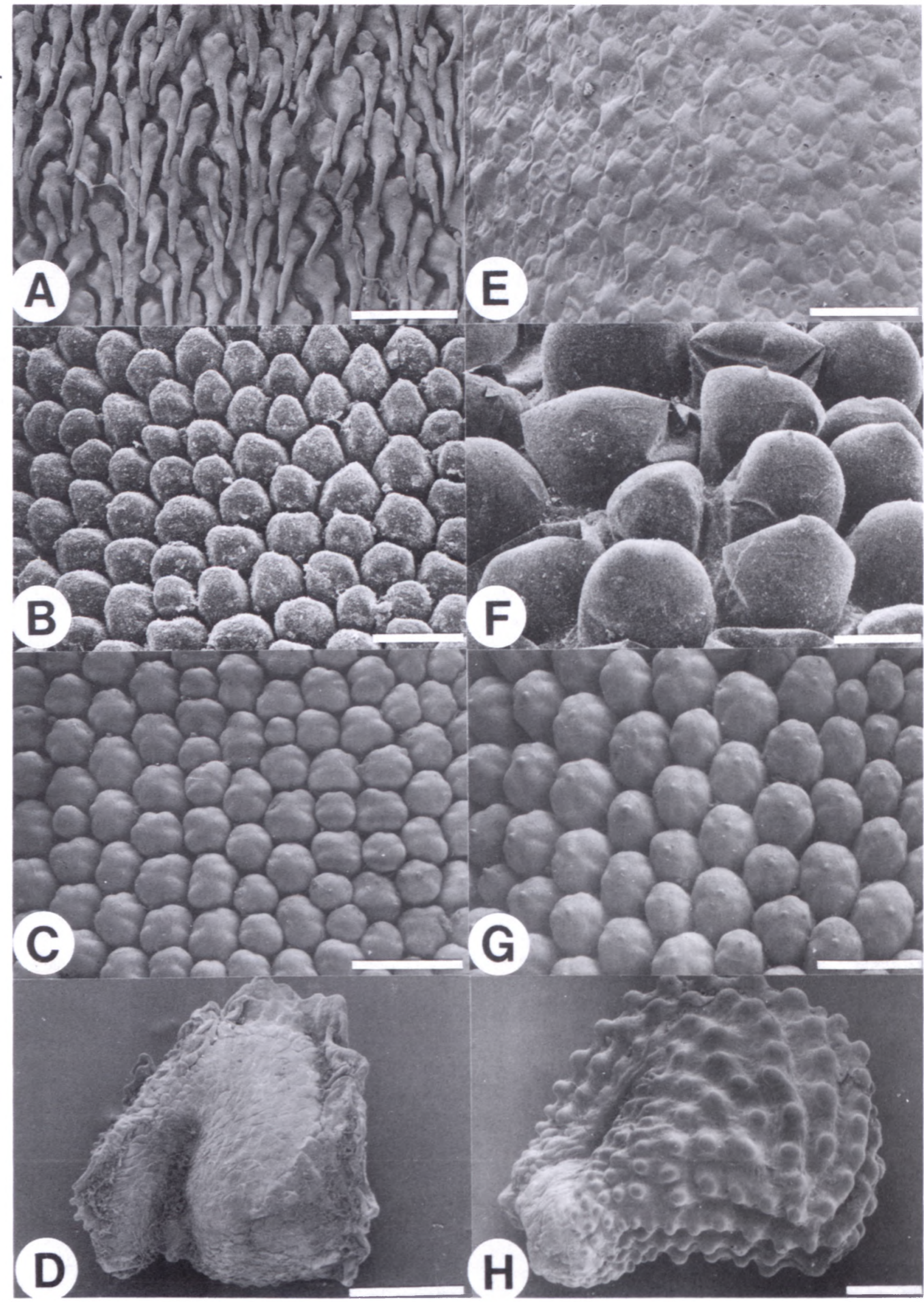

FIGURE 1.-Epidermal surface of Brownanthus. A-C: stems; E-G, leaves. A, E, B. glareicola, Klak 457; B, F, B. corallinus, Klak 64; C, G, B fraternus, Klak 171. D, H, seeds of Brownanthus: D, B. glareicola, Klak 457; H, B. fraternus, Klak 171. Scale bars: B, F, $200 \mu \mathrm{m}, \mathrm{A}, \mathrm{C}$, E, G, H, $250 \mu \mathrm{m} ; \mathrm{D}, 500 \mu \mathrm{m}$. 
Nieuwoudiville, (-AC), E.E. Galpin s.n., (BOL). 3218 (Clanwilliam): northeast of Pakhuis Pass, (-BB), Esterhuysen 32202 (BOL).

Note: the name 'maximilianii' is spelt here with 'ii' since 'Maximilian' is assumed not to be a latinized name and therefore 'maximiliani' needs to be corrected by adding an 'i' (ICBN Art. 60.11).

\section{Brownanthus Schwantes}

Brownanthus is one of 11 genera placed in the subfamily Mesembryanthemoideae. Apart from Psilocaulon N.E.Br., Aptenia N.E.Br. and Aspazoma N.E.Br., it is one of the few genera in the Aizoaceae in which stem succulence has developed (Bittrich 1986). At present ten species are recognised (Pierce \& Gerbaulet 1997). The main characteristics of the genus are that the sepals remain upright throughout anthesis, the white or creamcoloured flowers never possess any filamentous staminodes and the lower part of the capsule is shallowly bowl-shaped (Ihlenfeldt \& Bittrich 1985). Recent exploration in Western Cape has brought two new species to light both of which can unambiguously be placed in Brownanthus.

Brownanthus fraternus Klak, sp. nov., a B. corallino foliis minus papillosis manifeste, seminibus grandioribus cum tumore hilari differt.

TYPE.-Western Cape, 3420 (Bredasdorp): west of Swellendam, (-AA), Klak 17I (BOL, holo.; K).

Dwarf shrub, decumbent to erect, $150-400 \mathrm{~mm}$ high. $500 \mathrm{~mm}$ wide. Branches articulated, green, succulent, becoming woody with age towards bases; internodes cylindrical, $2.5-8.0 \times 3.5-4.0 \mathrm{~mm}$, epidermal bladder cells xeromorphic, \pm isodiametric (Figure 1C). Leaves deciduous, up to $9 \mathrm{~mm}$ long, flattened above, convex below, free towards bases, with mesomorphic epidermal bladder cells without hair-like extensions (Figure IG). Calyx with 5 lobes; lobes shortly connate and erect during anthesis. Flowers solitary, borne at tip of stem, 24 $\mathrm{mm}$ diam. Staminodes: petaloid staminodes white to cream-coloured, free to bases, recurving over calyx lobes; filamentous staminodes absent. Ovary semi-inferior; placentation axile. Fruit a hygrochastic capsule, 5locular, 5-7 mm diam., valve wings inflexed over expanded valves, seed bags absent. Seeds dark brown, Dshaped, 1.4-1.5 mm long, without crest, testa with raised central papillae, with hilar bulge (Figure $1 \mathrm{H}$ ). Flowering time: December.

Distribution and ecology: Bredasdorp and Swellendam Districts (Figure 2); on quartz patches overlaying clay or on gravelly shale slopes; winter rainfall up to $400 \mathrm{~mm}$.

\section{Specimens examined}

WESTERN CAPE - 3419 (Caledon): $10 \mathrm{~km}$ north of Napier. (-BD), Bruyns 6844 (BOL), Klak 275 (NBG); $2 \mathrm{~km}$ north of Napier, (-BD). Bruyns \& Klak 7807 (K). 3420 (Bredasdorp): west of Swellendam. (-AA), Klak 171 (BOL. holo.; K).

The habit, floral morphology and, in particular, the epidermal features of the stem of $B$. fraternus (Figure
1C) are very similar to those of $B$. corallinus (Thunb.) Ihlenf. \& Bittrich (Figure 1B), but the former may be distinguished by its less papillate leaves (Figure 1G). The most conspicuous difference lies in the seeds where there is a hilar bulge in B. fraternus (Figure $1 \mathrm{H}$ ), which is absent in B. corallinus.

B. fratemus is known from three localities between Swellendam and Bredasdorp, where it appears to be under threat from agricultural activities. This is much further south than any other Brownanthus and it is the only species of Brownanthus which grows on the coastal plains south of the Langeberg. The nearest locality of its closest relative, $B$. corallinus, is over $300 \mathrm{~km}$ to the northwest at the southern end of Namaqualand. The widespread, but less closely related $B$. ciliatus, is found no nearer than $100 \mathrm{~km}$ away from $B$. fraternus.

Brownanthus glareicola Klak, sp. nov., a $B$. corallino habitu parviore compactiore, pagina caulium hirta, foliis minus papillosis manifeste supra concavis infra convexis foliis junioribus imbricatis, seminibus cristatis distinguenda est.

TYPE.-Western Cape, 3118 (Vanrhynsdorp): southwest of Vanrhynsdorp. (-DA), Klak 457 (BOL, holo.; K).

Dwarf, erect shrub up to $170 \mathrm{~mm}$ high, $250 \mathrm{~mm}$ wide. Stems articulated, green, succulent, becoming slightly woody with age towards bases; internodes cylindrical, 3.5-5.5 × 3.5-4.5 mm, epidermal bladder cells xeromorphic with hair-like extensions (Figure 1A). Leaves deciduous, up to 3-5 mm long, concave above, convex below, overlapping at bases, epidermal bladder cells mesomorphic without hair-like extensions (Figure IE). Calyx with 5 lobes; lobes shortly connate and erect

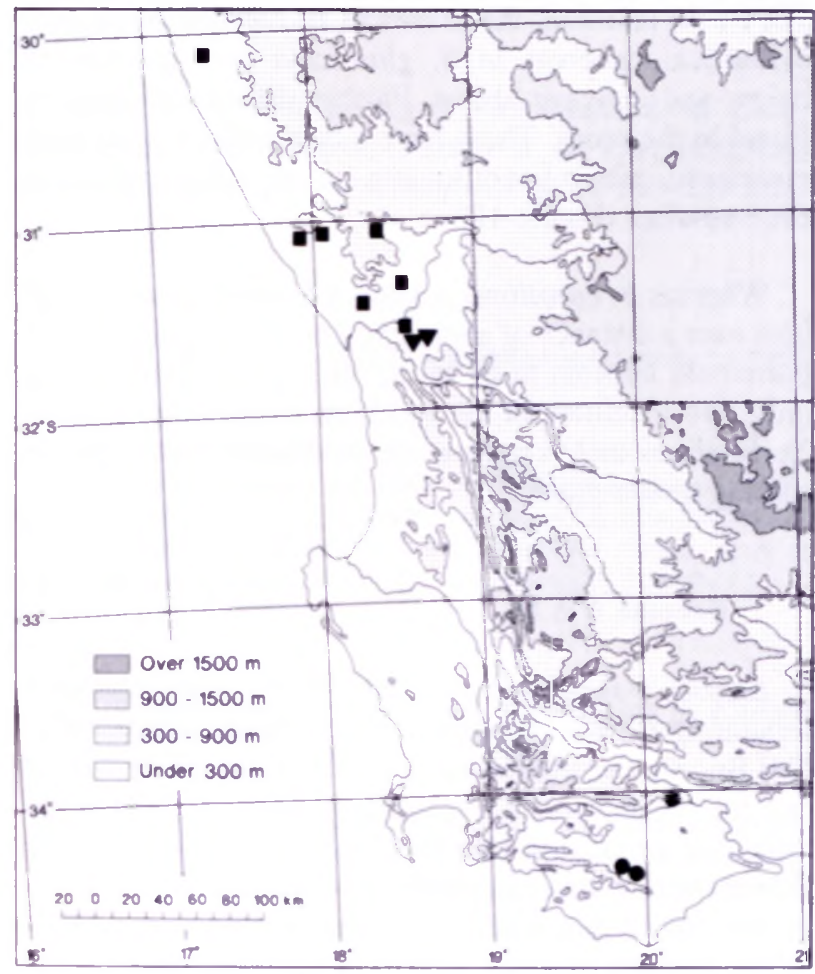

FIGURE 2-Distribution of Brownanthus glareicola B. coralli. nu. B. fraternus. 
during anthesis. Flowers solitary at tips of stems, 10-15 $\mathrm{mm}$ diam. Staminodes: petaloid staminodes white to cream-coloured, free to bases, recurving over calyx lobes; filamentous staminodes absent. Ovary semi-inferior; placentation axile. Fruit a hygrochastic capsule, 5locular, (4-)5-6 mm diam., valve wings inflexed over expanded valves, without seed bags. Seeds brown, Dshaped, 1.3-1.5 mm long, with a crest, hilar bulge absent, testa cells slightly raised (Figure ID). Flowering time: October.

Distribution and ecology: Knersvlakte, southwest of Vanrhynsdorp (Figure 2); flat to gently sloping patches of quartz gravel on clay; winter rainfall, 100-200 mm per year.

Etymology: glareicola $=$ gravel dweller .

\section{Specimens examined}

WESTERN CAPE.-3118 (Vanrhynsdorp): southwest of Vanrhynsdorp, (-DA), Klak 457 (BOL, holo.; K); gypsum mine. (-DA), Klak 458 (BOL)

The material upon which the description is based, comes from a locality south of Vanrhynsdorp, where the plants were first noticed by A. Ellis and P. Desmet in 1996. The species had previously been misidentified as Brownanthus corallinus and grows together with it in one of the known localities. The new species is distinctly smaller and more compact in growth than $B$. corallinus and the older stems are only slightly woody towards their bases. It also differs from $B$. corallinus (Figure IB) by the hair-like epidermal cells which cover the stems (Figure 1A). Furthermore, the bladder cell idioblasts of the leaves are noticeably more reduced in size compared to the ones in B. corallinus and the bases of young leaves overlap, which is never found in $B$. corallinus (Figure $1 \mathrm{E}, \mathrm{F})$. In addition, the leaves in $B$. corallinus are subcylindrical, whereas in $B$. glareicola they are convex below and concave above. Further differences may be found in the seeds. These have a conspicuous crest in $B$. glareicola, which is not known for any other species of Brownanthus (Figure 1D).

Whereas $B$. corallinus is known from numerous localities over a distance of about $250 \mathrm{~km}$ in Namaqualand, $B$. glareicola appears to be much rarer and is known from only two localities in the southern Knersvlakte (Figure 2 ). In all of these it grows on patches of flat to gently sloping quartz gravel.

\section{Erepsia N.E.Br.}

Erepsia was revised by Liede (1989). Characteristics separating it from the closely allied genus Lampranthus N.E.Br., are the triquetrous leaves with tough epidermis and the presence of a hypanthium. Liede (1989) subdivided the genus into four sections, three of which share flowers with vertical hypanthium walls and leaves usually less than $5 \mathrm{~mm}$ diam. The remaining section, Crassifoliae, consists of seven species in which the walls of the hypanthium are sloped outwards and the leaves are mostly fairly thick (5-10 mm diam.).
Recently, plants of the very rare Lampranthus dunensis were rediscovered on the Cape Flats. This species was described as Mesembryanthemum dunense by Sonder (1862). In Jacobsen (1960), L. Bolus moved it to Lampranthus and placed it in the informal section Reptantes.

An examination of the flowers of this material showed that they differ from those found in all species of Lampranthus, in that they possess a conspicuous, outwardly sloped hypanthium. In addition, the broad, triquetrous leaves with tough epidermis are typical of species placed in Erepsia section Crassifoliae. This feature, together with the noticable triquetrous leaves suggest that $L$. dunensis belongs in Erepsia. The leaves are 4-6 $\mathrm{mm}$ broad and fall within the limits included by Liede in Sect. Crassifoliae. It is now transferred to Erepsia.

Erepsia dunensis (Sond.) Klak, comb. nov.

Mesembryanthemum dunense Sond., Flora capensis 2 : 411 (1862) Lampranthus dunensis (Sond.) L.Bolus in Jacobsen: 1197 (1960) Syntypes: Western Cape, seashore near Cape Town, Ecklon s.n., Pappe s.n. (TCD, lecto.!, here designated; S).

Mesembryanthemum macrocalyx Kensit: 153 (1909). Type: Western Cape, Skurfkop near Somerset West, Nov. 1907, Pillans 1423 (BOL. holo.)

\section{Specimens examined}

WESTERN CAPE - 3418 (Cape Town): Sandvlei, (-AB), L. Bolus 18590 (BOL); Klipfontein Road, (-AB), Maytham s.n. (BOL); northwest of Fish Hoek, (-AB), Pillans 3626 (BOL): Zeekoevlei, (-AB), Siarke s.n. (BOL); Wolfgat Nature Reserve, (-BB), Klak 453 (BOL).

\section{Hammeria P.M.Burgoyne}

Hammeria was recently established for two species from the Ceres Karoo. The type of the genus is Hammeria salteri (L.Bolus) P.M.Burgoyne, with Ruschia salteri L.Bolus as its basionym (Burgoyne et al. 1998). Even more recently Hartmann (1998b) published a new name, Lampranthus tanquanus H.E.K.Hartmann, based on the same type, without reference to the earlier publication of Burgoyne et al. (1998).

The absence of closing bodies and the presence of valve wings were the reasons for excluding Ruschia salteri from Ruschia. Burgoyne et al. (1998) suggested morphological similarities to Antimima, Cheiridopsis and Chasmatophyllum, but were unable to place $R$. salteri into any of the existing genera. Hartmann (1998b) noted correctly that the fruits resembled those of the Titanopsis type, with thin, flexible, covering membranes bending down into the empty locules, and almost complete covering membranes. In addition, the locules are shallow, so that the lower part of the capsule is bowlshaped. In contrast, fruits of Lampranthus are always deep, \pm funnel-shaped, with firm, complete covering membranes and often additional closing devices below the covering membranes. It is therefore not possible for this species to remain in Lampranthus. From the capsule morphology, it appears more likely that closer relationships may be found with species placed in the Titanopsis or the Stomatium group. A closer study of this complex is needed before it can be decided whether Hammeria 
may be included in one of the existing genera or indeed deserves generic status.

However, it has so far been overlooked that the same species was named several times by L. Bolus. Since one of these names predates $R$. salteri, a new combination and synonomy are necessary.

Hammeria meleagris (L.Bolus) Klak, comb. nov. Mesembryanthemum meleagris L.Bolus, in Notes on Mesem-
brianthemum and allied genera, part 2: 17 (1928). Lampranthus melea-
gris (L.Bolus) L.Bolus: 169 (1939). Type: South Africa. Western Cape.
Ceres Div., near Karoopoort, Sept. 1928, Pillans 6130 (BOL, holo.!).

Lampranthus longisepalus L.Bolus: 169 (1939). Mesembryanthemum longisepalum L.Bolus: 198 (1930). Type: Western Cape, between Karoopoort and Calvinia, Jan. 1930, Leipoldt BOL19135 (BOL, holo.!)

Ruschia salteri L.Bolus: 371 (1932b). Hammeria salteri (L. Bolus) P.M.Burgoyne et al.: 206 (1998). Lampranthus tanquanus H.E.K.Harmann: 70 (1998b). Type: South Africa, Western Cape, beyond Karoopoort near the road to Sutherland, 3 Aug. 1932, Salter 2668 (BOL. lecto.!).

Lampranthus stoloniferus L.Bolus: 307 (1965). Type: South Africa, Western Cape, Sutherland Div., 55 miles east of Karoopoort, June 1965, F.J. Stayner KG2/4/65 (BOL, holo.!)

\section{Scopelogena L.Bolus}

Mesembryanthemum verruculatum was already known to Linnaeus and had been introduced to England in the early 1730's (Dillenius 1732). L. Bolus later placed this species in Lampranthus (Bolus 1950). The plant, however, could be separated from Lampranthus by the apparent lack of valve wings and the fact that the capsules do not close completely once they have opened. On the other hand it differs from Ruschia by the absence of closing bodies and by the yellow colour of the petals. These reasons prompted L. Bolus to establish a new genus, Scopelogena, in 1962 for this species. At the same time she described a second species of Scopelogena, $S$. gracilis L.Bolus (1962).

$S$. verruculata is known only from the Cape Peninsula, whereas $S$. gracilis was described from Grootvadersbosch, east of Swellendam. The latter was said to differ from $S$. verruculata by the more slender, sometimes obtusely keeled, often laterally compressed leaves, with the capsule obconical inside and not angled. Newly collected material from west and south of Swellendam has shown that none of these characters consistently separate $S$. verruculata from $S$. gracilis and that they are conspecific. $S$. verruculata is distributed from Cape Town sporadically eastwards to Herbertsdale, usually occurring on exposed, locally arid, sandstone outcrops.

These investigations have also shown that, contrary to previous descriptions (Bolus 1962), newly ripened capsules which were opened for the first time possessed very narrow, 'seam-like' valve wings. In most of the old capsules this character is no longer visible and this might explain the fact that it was not mentioned in previous descriptions.
Recent exploration has brought to light a second species, which occurs further north of the distribution area of $S$. verruculata. This is now described. Despite the large size of the plant, this species has so far been overlooked by most collectors. It is named after P.V. Bruyns, who was the first to notice it in Namaqualand in 1992.

Scopelogena bruynsii Klak, sp. nov., a $S$. verruculata floribus parvioribus luteis ad roseis salmoneisve, praesentia staminodiorum filamentosorum, fructibus repetite claudentibus discedit.

TYPE.-South Africa, Western Cape, Namaqualand, 3118 (Vanrhynsdorp): $10 \mathrm{~km}$ north of Nuwerus, (-AB), Klak \& Bruyns 462, (BOL, holo.; K).

Woody shrub up to $0.3 \mathrm{~m}$ high, $1 \mathrm{~m}$ wide, with stout, erect or spreading grey to brown stems. Leaves crowded, shortly connate, incurved, erect, 3-angled to cylindrical, up to $45 \times 5-8 \mathrm{~mm}$, bluntish, shortly mucronate, soft, whitish grey to slightly reddish. Calyx with 5 subequal lobes. Flowers in much-branched inflorescence; pedicels 4-11 mm long; bracts up to $15 \times 11 \mathrm{~mm}$. Staminodes: petaloid staminodes in 1 series; filamentous staminodes present, conically collected, papillate at bases; yellow, salmon or pale pink. Stamens erect, outer stamens papillate up to middle; anthers yellow; filaments same colour as staminodes. Nectaries in crenulate ring. Ovary semiinferior; stigmas filiform, shorter than tallest stamens; placentation parietal. Fruit a hygrochastic capsule, ochre, relatively soft and not woody, 5-locular, 3.0-4.5 $\mathrm{mm}$ diam., top convex, lower part deep, funnel-shaped, with very narrow valve wings when young, covering membranes present, almost completely covering locules, with fine ridge below covering membrane, expanding keels diverging, without closing body. Seeds dark brown, obovate, tuberculate, $1.0-1.1 \mathrm{~mm}$ long. Flowering time: September and October.

Distribution and ecology: Namaqualand to Clanwilliam and Ceres Karoo (Figure 3); on low, sandstone cliffs; in areas receiving winter rainfall of 100-200 $\mathrm{mm}$.

\section{Specimens examined}

NORTHERN CAPE-3018 (Kamiesberg): near Leeukuil, (-DC), Bruyns 5267a (BOL).

WESTERN CAPE - 3118 (Vanrhynsdorp): $10 \mathrm{~km}$ north of Nuwerus, (-AB), Klak \& Bruyns 462. (BOL, holo.: K): Matsikamma. (-DB), Helm 1656 (BOL). 3119 (Calvinia): Soutpan, (-CD), Klak 568 (BOL). 3219 (Wuppertal): Dassiekloof, (-BA), Klak 424 (BOL); south of Elandsvlei, (-DA), Klak 565 (BOL), Van Jaarsveld 13579 (BOL)

Scopelogena verruculata $(L)$ L. Bolus in Journal of South African Botany 28: 9 (1962).

Mesembryanthemum verruculatum L.: 486 (1753). Lampranthus verruculatus (L.) L.Bolus: 385 (1950). Ruschia verruculata (L.) G.D.Rowley: 9 (1978). Iconotype: Dill., Hon. Eltham. t. 203, fig. 259 (1732).

Scopelogena gracilis L Bolus: 10 (1962). Ruschia scopelogena G.D.Rowley: 9 (1978). Type: Westem Cape, Grootvadersbos, Dec, 1958. H. Hall 1506 (BOL, holo.!) 


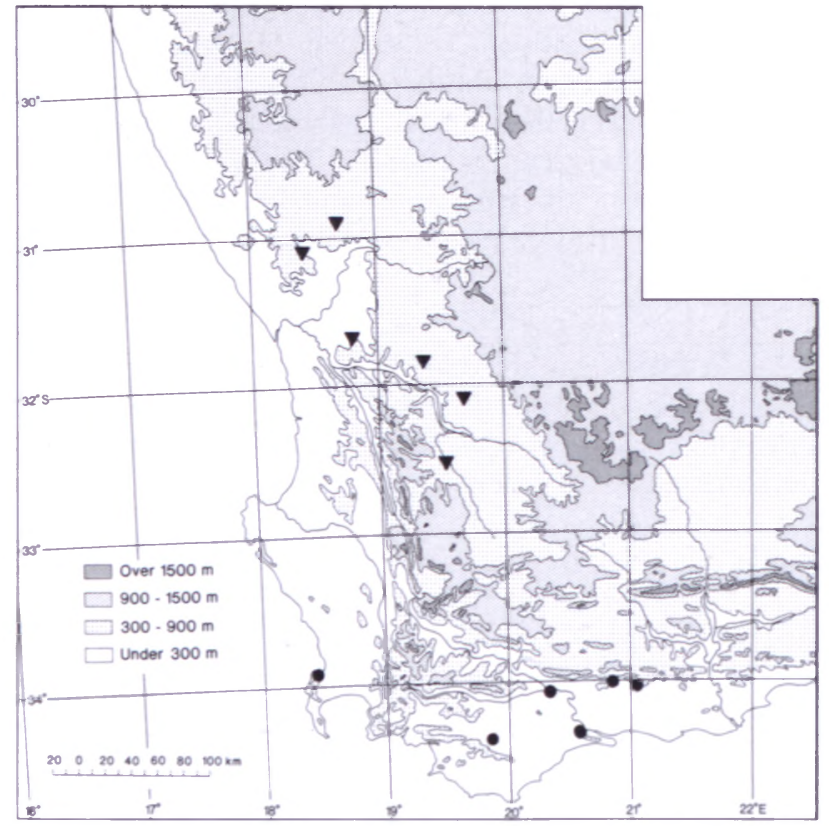

FIGURE 3.-Distribution of Scopelogena verruculata, Scopelogena bruynsii,

Woody shrub up to $0.3 \mathrm{~m}$ high, $2 \mathrm{~m}$ wide, with stout, erect or spreading, grey to brown stems. Leaves crowded, shortly connate, incurved, erect, 3 -angled to cylindrical, obtuse, up to $16-50 \times 3-5 \mathrm{~mm}$, shortly mucronate, very soft, grass green to grey or sometimes reddish. Calyx of 5 subequal lobes. Flowers in much-branched inflorescence; pedicels 4-15 mm long; bracts up to $15 \times$ $15 \mathrm{~mm}$. Staminodes: petaloid staminodes in 1 or 2 series, yellow rarely white; no filamentous staminodes observed. Stamens erect, outer stamens dorsally papillate up to middle, inner ventrally papillate at middle; anthers and filaments yellow. Nectaries in crenulate ring. Ovary semi-inferior; stigmas filiform, longer than stamens; placentation parietal. Fruit a hygrochastic capsule, not fully closing again once opened, ochre, relatively soft, not woody, 5-locular, 5-9 mm diam., top convex, lower part deep, funnel-shaped, with very narrow valve wings when young, covering membranes incomplete to almost complete, with inconspicuous ridge below covering membrane, expanding keels diverging, without closing body. Seeds dark brown, obovate, tuberculate, 1.1-1.2 mm long. Flowering time: September-October.

Distribution and ecology: Cape Peninsula to Riversdale (Figure 3); on sandstone cliffs, with winter rainfall of $300-600 \mathrm{~mm}$ annually.

\section{Specimens examined}

WESTERN CAPE. - 3318 (Cape Town): rocks west of Lion's Head, (-CD), Hall s.n. (BOL): Table Mountain, (-CD), Klak 318 (BOL), Marloth 2851 (BOL); Lion's Head, (-CD), Wolley Dod 2420 (BOL). 3419 (Caledon): $10 \mathrm{~km} \mathrm{~N}$ of Napier, Karsrivier, (-BD), Klak 278 (BOL). 3420 (Bredasdorp): 7 km W of Swellendam, (-AB), Klak 177 (BOL); Grootvadersbos, (-BB), Hall 1506 (BOL); Boskloof Potberg, (-BC), Burgers 1627 (NBG). 3421 (Riversdale): Glen Leith. (-AA), Muir 4320 (BOL)

S. verruculata and $S$. bruynsii are morphologically very similar and there appears to be no doubt that this new species belongs in Scopelogena. This is dispite the fact that in the new species the capsules open and close repeatedly. Consequently one of the main distinctions of Scopelogena (that the capsules remain open) falls away. Similar variability in this feature is also found in species of Aridaria (Gerbaulet 1996). The flowers of S. bruynsii may be yellow, pink or salmon-pink. $S$. verruculata has predominantly yellow or rarely white flowers.

S. bruynsii is found over a wide area, from Nuwerus to Clanwilliam and eastwards to the Ceres Karoo. The plants are always found growing on low sandstone cliffs.

The character combinations present in Scopelogena do not suggest clear affinities to any other genus in the Ruschiodeae and, consequently the relationships of Scopelogena need further study.

The correct identity of Mesembryanthemum purpureostylum L.Bolus

In recent literature, much confusion has arisen over the correct identity of Mesembryanthemum purpureostylum L.Bolus. The type was based on a collection from Bonnievale. L. Bolus later included this name in the synonymy of Ruschia forficata (L.) L.Bolus. Bruyns (1997) was the first to notice that in fact two different species were involved: $R$. forficata (L.) L. Bolus was found to be a synonym of Erepsia forficata (L.) Schwantes. Based on the presence of closing bodies and the absence of valve wings, Bruyns (1997) transferred M. purpureostylum to Ruschia, but, shortly afterwards, it was moved to Acrodon by Burgoyne (1998). In the same year, Hartmann (1998b) published a new combination in Cerochlamys based on the type of $M$. purpureostylum L.Bolus, however, without reference to any of these recent publications.

The absence of a capsule on the type poses some difficulties for the correct position of this species. However, a watercolour painting of the type specimen exists in the Bolus Herbarium (by M. Page) and this shows the habit, as well as the leaves and flowers. From this it is obvious that the flowers have their filamentous staminodes and stamens collected into a central cone, with the filamentous staminodes overtopping the stamens and partly concealing them. This arrangement is found in numerous other genera such as Ruschia and Antimima, but in none of the other species of Cerochlamys. In Cerochlamys the filamentous staminodes are loosely arranged in a cylinder around the stamens, sometimes with the outer ones spreading horizontally (Hartmann 1998b: 51, t. 16, 18, 20). The flower of Acrodon purpureostylus shown by Burgoyne matches that of the type. Hartmann, on the other hand, makes no mention of this typical cone flower.

In addition, Hartmann did not find any closing bodies in the capsules of the two collections which she cited. Both Bruyns and Burgoyne mention the presence of closing bodies in their collections. Both Bruyns' and Burgoyne's collections agree with the illustration of the type in all details of habit, leaves and flowers. It can therefore only be deduced that Hartmann must have based her conclusions on misidentified material. 
From the characteristics found to be typical of Acrodon (Hartmann 1996), Burgoyne (1998) showed conclusively that the species should be placed in Acrodon and no reasons have been put forward to alter this. A complete list of synonyms is given below.

\section{Acrodon purpureostylus (L.Bolus) P.M.Burgoyne} in Aloe 35: 60 (1998).

Mesembryanthemum purpureostylum L.Bolus: 6 (1920). Erepsia purpureostyla (L.Bolus) Schwantes: 68 (1928b). Ruschia purpureostyla (L.Bolus) P.V.Bruyns: 41 (1997). Cerochlamys purpureostyla (L.Bolus) H.E.K.Hartmann: 56 (1998b). Type: South Africa, Bonnievale. Mathews sub NBG3426/15, sheet 2 (BOL, lecto., here designated)

\section{The identity of Ruschia polita L.Bolus}

Until now much uncertainty has existed about the identity of Ruschia polita L.Bolus, which was described in 1932. The type specimen was collected by G. Nel at Touws River in April 1930. Bolus was uncertain whether this species belonged in Ruschia, as she placed a question mark next to the genus in her text. The absence of fruits on the type sheet may have added to the confusion. Annotations on the type sheet suggest that it belongs either in Corpuscularia or Antimima.

However, species placed in Corpuscularia are characterised by a peculiar epidermis, which is made up of tightly packed, dome-shaped epidermal bladder-cells. The surface of $R$. polita, on the other hand, consists of flattened cells and is completely smooth. In addition, species of Corpuscularia have so far only been recorded from a fairly small area around Port Elizabeth, in the Eastern Cape. Thus, the difference in epidermal morphology and the very disjunct distribution would suggest that the type specimen of Ruschia polita is unlikely to belong to Corpuscularia.

Exclusion of this species from Antimima and Ruschia is more difficult since the type lacks any fruits. Nevertheless, since Bolus did not mention the clustering of filamentous staminodes into a dense cone, it seems unlikely that it is either a species of Antimima or of Ruschia.

A notable feature of the type specimen is, however, its sharply keeled, thick leaves with cartilaginous margins. This is typical of species placed in Braunsia. The description of Braunsia geminata matches very closely that of Ruschia polita, both with respect to the morphology of the leaves as well as the flowers. In addition, the distribution of $B$. geminata extends from the Ceres Karoo to Prince Albert and the Little Karoo and so the type locality of $R$. polita falls within this area. Thus it is reasonable to conclude that $R$. polita is conspecific with B. geminata.

Braunsia geminata (Haw.) L. Bolus in Journal of South African Botany 33: 306 (1967).

Ruschia polita L.Bolus: 332 (19.32a): L.Bolus: 260 (19.54). Type Laingshurg Dist.; Touw's River, Apr 1930, G. Nel SUG9095 (BOL. holo.!).

\section{ACKNOWLEDGEMENTS}

This research was funded by the FRD, the Mesemb Study Group and the American Cactus and Succulent Society of America.

\section{REFERENCES}

BITTRICH, V. 1986. Untersuchungen zum Merkmalsbestand, Gliederung und Abgrenzung der Unterfamilie Mesembryanthemoideae (Mesembryanthemaceae Fenzl.). Mitteilungen aus dem Institut fur Allgemeine Botanik Hamburg 21: 5-116.

BOLUS, H.M.L. 1913. Mesembrianthemum. Annals of the South African Museum 9: 140-154.

BOLUS, H.M.L. 1920. Novitates africanae. Annals of the Bolus Herbarium 3:6

BOLUS, H.M.L. 1925. Novitates africanae. Annals of the Bolus Herbarium 4: 5 .

BOLUS, H.M. 1927. Mesembrianthemum binum. The Flowering Plants of South Africa 7: t. 263.

BOLUS, H.M.L. 1928. Notes on Mesembrianthemum and allied genera, part 2: 17-32. Bolus Herbarium. University of Cape Town

BOLUS, H.M.L. 1930. Notes on Mesembrianthemum and allied genera, part 2: 193-208. Bolus Herbarium. University of Cape Town.

BOLUS, H.M.L. 1932a. Notes on Mesembrianthemum and allied genera, part 2: 309-336. Bolus Herbarium. University of Cape Town.

BOLUS. H.M.L. 1932b. Notes on Mesembrianthemum and allied genera, part 2: 357-376. Bolus Herbarium. University of Cape Town.

BOLUS, H.M.L. 1939. Notes on Mesembryanthemum and allied genera. part 3: 139-188. Bolus Herbarium. University of Cape Town.

BOLUS, H.M.L 1950. Lampranthus verruculatus (L.) L.Bolus. In R.S Adamson \& T.M. Salter. Flora of the Cape Peninsula. Juta. Cape Town.

BOLUS, H.M.L. 1954. Notes on Mesembryanthemum and allied genera, part 3: 237-288.

BOLUS, H.M.L. 1962. Notes on Mesembryanthemum and allied genera. Journal of South African Botany 28: 9-11

BOLUS. H.M.L. 1965. Notes on Mesembranthemum and allied genera. Journal of South African Botany 31: 172, 307

BOLUS. H.M.L. 1967. Notes on Mesembryanthemum and allied genera. Journal of South African Botany 33: 308, 309.

BROWN. N.E. 1929. New species and critical notes on Mesembrvanthemum and allied genera. Kew Bulletin 1929: 56-62.

BROWN, N.E. 1930. Mesembryanthemum. The Gardeners 'Chronicle. ser. 3, 87: 13-211

BRUYNS. P.V. 1997. A new combination in the genus Ruschia and the correct name for 'Cynanchum capense'. South African Journal of Botany $63: 241$.

BURGOYNE. P.M. 1998. Finding a place in the sun: where does Ruschia purpureostrla belong? Aloe $35: 60,61$.

BURGOYNE. P.M. SMITH, G.F. \& CHESSELET. P 1998. Hammeria, a new genus of Aizoaceae from South Africa. Cactus and Succulent Journal (US) 70: 203-208.

DEHN. M. 1989. Untersuchungen zum Merkmalsbestand und zur Stellung der Gaftung Antimima NEBr. emend. Dehn (Mesembryanthemaceae Fenzl.) Mitteilungen aus dem Institut fü Allgemeine Botanik Hamburg 22: 189-215.

DILLENIUS, J.J. 1732. Hortus elthamensis: 268. t. 203, fig. 259 Londini. sumptibus auctoris

GERBAULET. M. 1996. Revision of the genus Aridaria N.EBr (Aizoaceae). Botanische Jahrbücher 118: 41-58

GREUTER. W., BARRIE. FR., BURDET. HM. CHALONER. W G. DESMOLLIN, V., HAWKSWORTH. D.L., JORGENSEN, P.M. NICOLSON, D.H. SILVA, P.C. TREHANE. P \& MCNEILL. J. (eds). 1994: International Code of Botanical Nomenclature, adopted by the Fifteenth International Botanical Congress, Yokohama. August-September 1993. Königstein.

HARTMANN. H.E.K 1991 Mesembrunthema. In H.P. Linder \& A.V Hall. Systematics, biology and evolution of some South African taxa. Contributions from the Bolus Herburium 13: 75-157

HARTMANN. HEK 1996. Miscellaneous taxonomic notes on Aizoaceae. Bradleya 14: 29-56

HARTMANN. HEK 1998a. New combinations in Antimima (Ruschioideae. Aizoaceae) from southem Africa. Bothulia 28 : 67-82. 
HARTMANN, H.E.K. 1998b. New combinations in Ruschioideae based on studies in Ruschia (Aizoaceae). Bradleya 16: 44-91.

IHLENFELDT, H.-D. \& BITTRICH, V. 1985. Morphologie, Gliederung und Abgrenzung der Gattung Psilocaulon N.E.Br. s.l. (Mesembryanthemaceae). Botanische Jahrbücher 105: 289-322.

JACOBSEN, H. 1960. A handbook of succulent plants 3. London.

KENSIT, H.M.L. 1909. Contributions to the African flora. Transactions of the Royal Society of South Africa 1: 153.

LIEDE, S. 1989. Untersuchungen zum Merkmalsbestand und zur Taxonomie der Erepsiinae (Mesembryanthemaceae). Beiträge zur Biologie der Pflanzen 64: 391-479.

LINNAEUS, C. 1753. Species plantarum, edn 1: 486. Salvius, Stockholm.
PIERCE, S.M. \& GERBAULET, M. 1997. Brownanthus Schwantes (Mesembryanthemoideae, Aizoaceae): two new species and a new combination from the Richtersveld and southwestern Namibia. Aloe 37: 42-44.

ROWLEY, G. 1978. Reunion of some genera of Mesembryanthemaceae. The National Cactus \& Succulent Journal (UK) 33: 6-9.

SCHLECHTER, F.R.R. \& BERGER, A. 1922. Mehrere neue Mesem brianthemum und eine Aloe. Botanische Jahrbücher 57: 626-644.

SCHWANTES, G. 1928a. Braunsia. Gartenwelt 32: 644

SCHWANTES, G. 1928b. Mesembriaceen unserer Kulturen in neuer Benennung. Gartenflora 77: 68, 69

SONDER, O.W. 1862. Mesembryanthemum. In W.H. Harvey \& O.W Sonder, Flora capensis 2: 395-460. 


\title{
Notes on African plants
}

\author{
VARIOUS AUTHORS
}

\section{AGAVACEAE}

\author{
AGAVE VIVIPARA: A NATURALISED ALIEN IN SOUTHERN AFRICA
}

invasive species are a kind of habitat destruction. When invasive species take over a habitat, they erase the native richness and diversity of species. What we really need is an everyday concern among ordinary people about biodiversity and the issue of invasiveness."

-Dr Vandana Shiva in conversation with IUCN's Ricardo Bayon (1997-1998)

The indigenous succulent flora of southern Africa represents 55 mostly unrelated plant families and includes all possible types of life forms. A small minority of exotic succulents (24 species according to Smith et al. 1997) can be regarded as naturalised in southern Africa. These species are mostly representative of the Cactaceae (19 species) and, to a much lesser degree, the Basellaceae (1 species), Agavaceae (2 species) and Portulacaceae (2 species) (Smith et al. 1997). Some of the species of Cactaceae, e.g. Opuntia ficus-indica (L.) Mill. (prickly pear) and $O$. aurantiaca Lindl. (jointed cactus) are aggressive noxious weeds that have invaded and transformed certain parts of the southern African landscape

In recent years, at least among urban gardeners, the popularity of agavaceous taxa is seemingly on the increase. The plants are being used as inexpensive, permanent barriers to ward off intruders. With their formidable spines, large and compact habit, drought resistance and aggressive growing capability, they are ideally suited for this purpose. With the abandonment of habitations, these hardy agaves can persist without human intervention and subsequently become adventive aliens (Kloot 1987) in the local flora. One such species, Agave decipiens Baker was recently recorded in South Africa (Smith \& Steyn 1999a). This paper deals with a comparable alien, namely $A$. vivipara L. var. vivipara.

Agave vivipara, often known by one of its synonyms, A. angustifolia Haw., is a variable species native to central America (Gentry 1982; Forster 1992). It is thought that the species was the wild ancestor of henequén ( $A$. fourcroydes Lem.), a cultivated species known worldwide for the high quality of its fibres (ColungaGarcíaMarín \& May-Pat 1993; Colunga-GarcíaMarín et al. 1999). Mr Bernard Ulrich (Pforzheim, Germany) has in turn suggested to the second author that $A$. vivipara is possibly a selected form of the widely cultivated $A$. sisalana Perrine, source of sisal hemp. Currently, six varieties, including the typical variety, and two cultivars are recognised in A. vivipara (Forster 1992). According to Gentry (1982), this species complex has the most wide-ranging distribution of agaves in North America (for a list of exsiccatae see Gentry 1982: 586-590). The plants commonly occur in tropical savanna, thorn forest and drought-deciduous tropical forests. However, the species also survives in extreme habitats such as the arid Sonoran Desert with about $250 \mathrm{~mm}$ rain per annum and in montane pine-oak forests with a yearly precipitation of
$1680 \mathrm{~mm}$. In these natural habitats, wild populations of A. vivipara exhibit a gradient in morphological variation, with characters such as plant size, length of leaves, distribution of marginal teeth and mass of leaf fibres showing a high degree of plasticity. Also, improved growth conditions in gardens result in an increase in leaf length and fibre content and a decrease in thorniness (ColungaGarcíaMarín \& May-Pat 1997).

Since pre-Hispanic times, wild populations of $A$. vivipara have been prized by the inhabitants of central America not only for their fibres-which are used for hammocks, bags and fabrics-but also, the peduncles, leaves, stems and roots are used for building material, utensils, tools, food, fermented beverages and medicine (Cruz-Ramos et al. 1985; Colunga-GarcíaMarín \& MayPat 1993; Nobel 1994). With increasing attention being paid to the utilisation of invasive aliens (Zimmermann \& Zimmermann 1987; Anon. 1988; Howell \& Schnell 1991; Turksvykwekersvereniging 1997), southern African environmentalists should take cognisance of the Mexican ethnobotanical uses of $A$. vivipara with a view to duplicating some of these practices locally.

The typical variety of $A$. vivipara is easy to distinguish from $A$. decipiens, the only species with which it can be confused in southern Africa. Important morphological distinctions between the two taxa are given below (Table 1).

TABLE 1 - Main morphological distinctions between Agave decipiens and $A$. vivipara

\begin{tabular}{|c|c|c|}
\hline Character & Agave decipiens & Agave vivipara \\
\hline Habit & $\begin{array}{l}\text { Lax rosette crowned by } \\
\text { young leaves: stem } \\
\text { distinctly thickened by } \\
\text { broad leaf bases }\end{array}$ & $\begin{array}{l}\text { Compact rosette with } \\
\text { very shor internodes; } \\
\text { stem not perceptibly } \\
\text { thickened by leaf bases }\end{array}$ \\
\hline Leaves & $\begin{array}{l}\text { Mature leaves laxly dis- } \\
\text { posed horizontally and } \\
\text { downward, firm in tex- } \\
\text { ture. not very fibrous, } \\
\text { leaf blades concave } \\
\text { above, convex below, } \\
\text { cymbiform in transverse } \\
\text { section }\end{array}$ & $\begin{array}{l}\text { Mature leaves radiating, } \\
\text { ascending to descending. } \\
\text { hard-fleshy, massively } \\
\text { fibrous. leaf blades flat in } \\
\text { transverse section }\end{array}$ \\
\hline Leaf margin & Sinuously toothed & Straight \\
\hline Marginal teeth & $\begin{array}{l}\text { Small. 1-2 mm long. } \\
\text { straight to decurved. on } \\
\text { low green prominences. } \\
\text { firmly attached to leaf } \\
\text { margin }\end{array}$ & $\begin{array}{l}\text { Large. up to } 5 \mathrm{~mm} \text { long. } \\
\text { with broad bases and } \\
\text { slender, decurved } \\
\text { (hooked) cusps, easily } \\
\text { detachable }\end{array}$ \\
\hline Inflorescence & $\begin{array}{l}\text { Umbellate branches } \\
\text { gracefully upcurved }\end{array}$ & $\begin{array}{l}\text { Umbellate branches } \\
\text { spreading horizontally }\end{array}$ \\
\hline Flowers & $\begin{array}{l}\text { Emitting a strong, fetid } \\
\text { scent }\end{array}$ & $\begin{array}{l}\text { Scented, but not foul- } \\
\text { smelling }\end{array}$ \\
\hline
\end{tabular}

